\title{
Effects of Theme-Based Garden Book Making in Capstone Design on Self-Determination and Social Skills of College Students with Developmental Disabilities
}

\author{
Soo Yeon $\mathrm{Kim}^{*}$ \\ Professor, Department of Rehabilitation Independence, Korea Nazarene University, Cheonan 456, Korea
}

\section{ABSTRACT}

Background and objective: This study was conducted to examine the effects of the theme-based garden book (photo book) making integration program on social skills and self-determination of college students with developmental disabilities. Methods: We analyzed the changes in social skills and self-determination of college students with developmental disabilities. The first step was defining the theme-based garden book (photo book) making integration program, which was done by focus group interviews (FGI) comprised of specialists in the industry and academia. The second step was carrying out 8 sessions of the program. The third step was examining the effects of the program on social skills and self-determination of college students with developmental disabilities. The participants of this study were 36 college students with developmental disabilities attending N University, and 17 students were in the experiment group and the other 19 in the control group.

Results: The control group showed no statistically significant changes in the three sub-domains of social skills, while the experimental group showed statistically significant differences across all three sub-domains, such as cooperation $(P<.05)$, assertion $(P<.05)$, and self-control $(P<.05)$. The experimental group, that participated in the program showed statistically significant differences across all four sub-domains of self-determination skills, such as behavior $(P<.05)$, cognition $(P<$ .05), school support $(P<.05)$ and home support $(P<.05)$. This proved that the theme-based garden book (photo book) making program contributed to bringing positive effects to self-determination and social skills.

Conclusion: These results suggest that the theme-based garden book (photo book) making integration program could improve self-determination and social skills of college students with developmental disabilities. These positive changes are related to the high level of interest in theme-based garden design programs among college students with developmental disabilities, and thus these programs can be used effectively to improve social adjustment.

Keywords: autism, book design, gardening design, social adjustment, project

\section{Introduction}

Human beings mature and grow as they properly build relationships with others and naturally acquire social skills in life. These social skills are specific adaptive behavior that helps rationally resolve conflicts and socially accept them (Kim, 1996). Therefore, social skills must be developed sufficiently for successful adaptive behavior, but so- cial adjustment is difficult for persons with developmental disabilities due to lack of social skills (Elliot and Cavell, 1990). Developmental disabilities include intellectual disability and autism spectrum disorder. Intellectual disability makes social adjustment difficult as mental development is permanently delayed, resulting in incomplete development of intellectual capacity. Autism spectrum disorder is a disability in self-regulation of verbal and physical ex-

\footnotetext{
This Research was supported by the Korea Nazarene University Research Grants 2020.

Received: December 5, 2020, Revised: December 22, 2020, Accepted: January 20, 2021

First author: Soo Yeon Kim, ksy0713@kornu.ac.kr, (D) https://orcid.org/0000-0002-1130-454X

*Corresponding author: Soo Yeon Kim, ksy0713@kornu.ac.kr, (10) https://orcid.org/0000-0002-1130-454X
} 
pressions, thereby in need of other people's help in daily or social life (http://www.moleg.go.kr., 2016). In other words, persons with developmental disabilities have difficulty in subjective perception or self-determination in their lives, face social maladaptation due to lack of social skills, and even show impulsive behaviors (Park, 2018). Therefore, they constantly need social adjustment programs to improve self-determination and social skills. Meanwhile, there are studies proving that book making enhances individual values and gives pride and confidence to persons with developmental disabilities including autism spectrum disorder (Hue, 2009; Kim, 2013) and that gardening is effective for social adjustment of persons with developmental disabilities and the perfect curriculum (Royal Horticultural Society, 2018) that can be integrated with various fields (Kim, 2018; Lee et al., 2012). Based on these studies, we will adopt a theme-based garden book (photo book) making program that combined book making with the benefits of garden design and verify its effects. This is also an attempt to verify the validity of using garden design in the integrated program, as the Fourth Industrial Revolution has recently accelerated connection and convergence of different fields. Capstone design teaching was used in this study, which is not a one-way teaching method of the instructor but a method in which learners produce outcomes by carrying out projects with the knowledge, skills, and attitudes they learned, and it promotes learning through discussions and interactions among participants to achieve a shared goal (On, 2019). Thus, as learners cooperate in teaching and learning, they can improve their self-directedness and acquire social skills such as communication skills in the learning process to understand each other by freely expressing their opinions and listening to others (Roseth et al., 2008). Therefore, the research question of this study is whether the theme-based garden book

making integration program affects social skills and self-determination skills of college students with developmental disabilities, which is statistically verified with a capstone design project. Accordingly, the ultimate goal of this study is to objectify the validity of using a garden design program in improving social skills and self-determination skills, which are fundamental for social adjustment of college students with developmental disabilities, and provide the possibility of various integration programs in the field of garden design.

\section{Research Methods}

\section{Subjects}

The subjects are undergraduate students in the specialized department with developmental disabilities at $\mathrm{N}$ University located in $\mathrm{C}$ city. The class was conducted in Class A and Class B at the same time. 17 students applied to participate in the capstone design class for the experimental group as Class A, and 19 students in the same department taking another elective course on general theories were assigned to the control group as Class B. The students were notified that the capstone design class as an elective course for the major is to be conducted in the laboratory focusing on indoor garden activities, and we received applications by order of arrival during the course registration period. The subjects were students possessing the registration certificate for a person with a disability according to Article 32 of the Act on Welfare of Persons with Disabilities, who have borderline and mild disabilities (Level 3 developmental disabilities), whose parents approved participation, and who passed N University's own criteria for scholastic ability. There were 13 male and 4 female students in the experimental group Class A, and 13 male and 6 female students in the control group Class B.

\section{Tools}

\section{Experimental design}

This study was conducted to determine the effects of the theme-based garden book (photo book) making integration program with the capstone design class on self-determination and social skills of college students with developmental disabilities. We analyzed the changes in the subjects using the pretest-posttest design. Here, the materials costs, filming, publishing, and printing process were funded by the capstone design project budget of $\mathrm{N}$ University. The subjects were put into groups of 4 or 5 members, and 5 assistants participated in the class to help 
out in the lab settings.

\section{Program design}

A focus group was formed with experts that have experience teaching college students with developmental disabilities. The focus group had total 6 experts: 3 professors in charge of educating students with developmental disabilities at $\mathrm{N}$ University and 3 field specialists with experience in horticultural programs for developmental disabilities. One of the field specialists was specialized in horticulture and two were specialized in rehabilitation and welfare. They had at least two years of experience participating in horticulture and rehabilitation programs at relevant institutions and schools. They are specialized coordinators at the specialized department of $\mathrm{N}$ University guiding college students with developmental disabilities through their studies and life. The garden activities program was reconstructed to be more suitable for college students with developmental disabilities through focus group interviews (FGI). For garden activities, we reviewed the experience-based program 'From Seeds to Flower Cafés' developed by the Rural Development Administration's National Institute of Horticultural \& Herbal Science and the Environment Training Institute's program 'Environment One, Two, Three' approved by the Ministry of Environment (Ministry of Environment Certification No. 2014-119). Then, we decided to organize the program with focus on planting among indoor garden activities, which can be effectively filmed, to consistently create a photo book of the structuralized garden design process considering the characteristics of learners who have developmental disabilities and come up with the results of theme-based garden book making. Moreover, we set the theme for each group, came up with a story, and structuralized garden activities through FGI. The capstone design class is a class in which learners carry out actual projects with their knowledge, skills, and attitudes and produce outcomes. We classified the theme-based garden book (photo book) making process into five steps, such as filming, drafting, revision, editing, and publishing, and then made detailed plans as shown in Table 1.

\section{Program implementation}

This study carried out the program in total 8 sessions once a week from 12:00 p.m. to 3:00 p.m. every Tuesday for 3 hours each at the Able Center, which is an exclusive laboratory for developmental disabilities at $\mathrm{N}$ University, from October to November 2019. The experimental group was comprised of 17 subjects that applied for the capstone design, participating in total 8 sessions of the program once a week. The program first began with Step 1 in which the subjects build rapport, after which they can experience social skills in FGI. The initial stage was to promote intimacy and interest, the middle stage was to induce assertion, cooperation, and self-control as well as to improve cooperation, and the final stage was to select related themes with continuous cooperation and come up with a story by sharing thoughts in groups. As the sub-factors of social skills, cooperation is the ability to solve problems with others, assertion is the ability to express one's rights and opinions, and self-control is the ability to manage and control one's own actions. Thus, prior to creating a garden, the subjects connected the theme that expresses their emotions to social skills and formed a story in the order of past, present, and future. The program details in Table 1 show that the theme of each session is developed, such as the memory garden recalling childhood memories, vision garden talking about future hopes, well-being garden talking about health, their own character garden, and preserved garden to value and preserve. After that, in Step 2, the subjects created garden designs based on the given theme, selected materials, and created their own mini gardens. In Step 3, they wrapped up the theme garden making produces, took photos, arranged them in order, presented their thoughts and feelings, and exchanged feedback. The sessions of the program were carried out in this order. Sessions 1 through 6 were carried out in the same method, while in Session 7, the photos gathered are edited on the computer using Photoshop samples on www.snap.com to edit and publish them in the form of a photo book. The design program on www.snap.com was used to make up for the limitations students with developmental disabilities have in professional book editorial design. In Session 8, the subjects shared their thoughts and feelings about the final out- 
Table 1. Making a garden book with theme integration program used in this study

\begin{tabular}{|c|c|c|c|c|c|}
\hline Session & Title & $\begin{array}{c}\text { Setting up } \\
\text { Theme of story }\end{array}$ & $\begin{array}{c}\text { Filming of } \\
\text { gardening step }\end{array}$ & Garden activity & Book making activity \\
\hline 0 & Orientation & $\begin{array}{l}\text { Self introduction } \\
\text { for rapport } \\
\text { building }\end{array}$ & & $\begin{array}{l}\text { - Planning of garden design } \\
\text { contents according to theme }\end{array}$ & $\begin{array}{l}\text { - Introducing own's story } \\
\text { - Talking about own's favorate } \\
\text { things } \\
\text { - Choosing a theme by subject }\end{array}$ \\
\hline 1 & $\begin{array}{l}\text { Memory } \\
\text { garden }\end{array}$ & $\begin{array}{l}\text { Searching for } \\
\text { childhood } \\
\text { memories }\end{array}$ & & $\begin{array}{l}\text { - Understanding of terrarium } \\
\text { principle } \\
\text { - Gathering of transparent goods } \\
\text { - Making drain layer } \\
\text { - Planting plants step by step } \\
\text { - Watering plants } \\
\text { - Taking care of small plants }\end{array}$ & $\begin{array}{l}\text { - Choosing a topic of memory } \\
\text { garden } \\
\text { - Filming of production process } \\
\text { - Lay out photos in PC }\end{array}$ \\
\hline 2 & $\begin{array}{l}\text { Hanging } \\
\text { (vision) } \\
\text { garden }\end{array}$ & $\begin{array}{l}\text { Setting the } \\
\text { future vision }\end{array}$ & & $\begin{array}{l}\text { - Understanding of hanging } \\
\text { garden principle } \\
\text { - Making drain layer } \\
\text { - Planting plants step by step } \\
\text { - Watering plants } \\
\text { - Taking care of plants }\end{array}$ & $\begin{array}{l}\text { - Choosing a topic of vision } \\
\text { garden } \\
\text { - Filming of production process } \\
\text { - Lay out photos in PC }\end{array}$ \\
\hline 3 & $\begin{array}{l}\text { Wellbeing } \\
\text { garden }\end{array}$ & $\begin{array}{l}\text { Health caring for } \\
\text { life goal }\end{array}$ & & $\begin{array}{l}\text { - Understanding of effect of } \\
\text { charcoal garden } \\
\text { - Making charcoal garden } \\
\text { - Planting plants within charcoal } \\
\text { - Watering plants } \\
\text { - Taking care of plants }\end{array}$ & $\begin{array}{l}\text { - Choosing a topic of wellbeing } \\
\text { garden } \\
\text { - Summary of charcoal garden } \\
\text { - Filming of production process } \\
\text { - Lay out photos in PC }\end{array}$ \\
\hline 4 & My garden & $\begin{array}{l}\text { Making character } \\
\text { of my garden }\end{array}$ & & $\begin{array}{l}\text { - Making of garden goods with } \\
\text { recycling materials } \\
\text { - Making of my face with plants }\end{array}$ & $\begin{array}{l}\text { - Making of my character image } \\
\text { - Making of my faverate goods } \\
\text { - Making character of my garden }\end{array}$ \\
\hline 5 & $\begin{array}{l}\text { Dream } \\
\text { garden }\end{array}$ & $\begin{array}{l}\text { Clean up of bad } \\
\text { things for our } \\
\text { dream }\end{array}$ & & $\begin{array}{l}\text { - Understanding of hydroponics } \\
\text { principle } \\
\text { - Choosing a plants } \\
\text { - Clean up plants } \\
\text { - Making of water garden } \\
\text { - Taking care of water garden }\end{array}$ & $\begin{array}{l}\text { - Choosing a topic of hobby } \\
\text { garden } \\
\text { - Filming of production process } \\
\text { - Lay out photos }\end{array}$ \\
\hline 6 & $\begin{array}{l}\text { Preserved } \\
\text { garden }\end{array}$ & $\begin{array}{l}\text { Gathering the } \\
\text { special plants }\end{array}$ & & $\begin{array}{l}\text { - Observing beautiful flowers } \\
\text { - Observing beautiful plants }\end{array}$ & $\begin{array}{l}\text { - Choosing a topic of searching } \\
\text { for forest } \\
\text { - Filming of production process } \\
\text { - Lay out photos } \\
\text { - Communication with photo frame }\end{array}$ \\
\hline 7 & $\begin{array}{l}\text { Final } \\
\text { presentation } \\
\& \text { feedback }\end{array}$ & $\begin{array}{l}\text { Set up the photo } \\
\text { contents finally }\end{array}$ & & $\begin{array}{l}\text { - Summary of theme garden } \\
\text { design process by discussion }\end{array}$ & $\begin{array}{l}\text { - Searching for website } \\
\text { www.snap.com } \\
\text { - Team presentation \&feedback }\end{array}$ \\
\hline 8 & $\begin{array}{c}\text { Communicati } \\
\text { on with book } \\
\text { publishing }\end{array}$ & $\begin{array}{l}\text { Design for book } \\
\text { cover and editing }\end{array}$ & & $\begin{array}{l}\text { - Communication with effect of } \\
\text { garden activity finally }\end{array}$ & $\begin{array}{l}\text { - Communication with editing } \\
\text { and publishing }\end{array}$ \\
\hline
\end{tabular}


put, the photo books completed and published by each group, listened to the presentation of other groups and exchanged feedback, and shared opinions about use of completed books, thereby reflecting on themselves and wrapping up. To help the subjects experience cooperation, self-expression, and self-control by verbally expressing their thoughts and feelings and interacting with one another in this step, the program was carried out by an instructor with much experience in design education for persons with developmental disabilities, and teaching assistants assisted each group throughout the entire process.

\section{Evaluation tools and analysis methods}

\section{Evaluation tools}

(1) Test of self-determination skills

To measure self-determination skills of college students with developmental disabilities, we used the self-determination skills scale for students among the self-determination skills rating system modified and adapted by Rhyou (2002) and remodified by Kim (2011). This tool rates self-determination skills on a 5-point Likert scale. The purpose of this test is to improve self-determination skills of students, and Cronbach's $\alpha$ to estimate the internal consistency and reliability of the items is .92 .

\section{(2) Test of social skills}

To measure social skills, we used the social skills scale among the social skills rating system by Elliot and Gresham (1990), which was modified and adapted by Kim (1996). This scale is comprised of 3 sub-domains: cooperation, assertion, and self-control. Each sub-domain has 20 items, and Cronbach's $\alpha$ of the social skills scale is .85 .

\section{Analysis methods}

This study tested self-determination and social skills of college students with developmental disabilities once before and after the program. Data was analyzed with IBM SPSS Statistics 21.0, testing normality before the paired t-test to analyze the pretest-posttest changes of the subjects, after which we analyzed changes after the program. The homogeneity of the control group and experimental group was tested with an independent t-test.

\section{Limitations}

1) We reviewed the indoor and outdoor garden activities and the book making program on 36 college students with developmental disabilities (intellectual disability and autism spectrum disorder) attending $\mathrm{N}$ University, a four-year university in Chungcheongnam-do, after which we reconstructed the program with consultation of the committee of experts through FGI, and thus there are limitations in generalizing the results of 36 subjects to all persons with developmental disabilities with individualized characteristics.

2) The scope of book making in this study is limited to a photo book focused on photos, and thus only some parts of the book making process are used in this study.

3) While testing self-determination and social skills, the instructor specialized in developmental disabilities explained the items or questions that are difficult for college students with developmental disabilities to understand during the survey. Thus, there were partial limitations in accurately evaluating the responses as a self-administered survey.

4) There are various control factors affecting self-determination and social skills, but in this study, they were limited to effects of applying a theme-based garden book (photo book) making program.

5) The results of this study analyzed the effects of the theme-based garden book making integration program and thus there are limitations in determining the effects of using capstone design and analyzing the individual effects of book making and garden activities.

\section{Results and Discussion}

\section{Preliminary test of homogeneity between groups}

To test the homogeneity of the two groups before carrying out the program using an independent t-test, we con- 
Table 2. Preliminary homogeneity test of self determination skill and social skill in the control and experimental group

\begin{tabular}{|c|c|c|c|c|c|}
\hline Iten & & Exp. & Cont. & $\mathrm{t}$ & $p$ \\
\hline \multirow{4}{*}{ Self determination skill } & Behavior & $3.35 \pm 0.94$ & $3.48 \pm 0.85$ & -.453 & $.653^{\mathrm{NS}}$ \\
\hline & Cognition & $3.52 \pm 0.82$ & $3.43 \pm 0.89$ & .308 & $.760^{\mathrm{NS}}$ \\
\hline & School support & $3.30 \pm 0.77$ & $3.31 \pm 0.80$ & -.183 & $.856^{\mathrm{NS}}$ \\
\hline & Home support & $3.52 \pm 0.98$ & $3.63 \pm 0.91$ & -.339 & $.737^{\mathrm{NS}}$ \\
\hline \multirow{3}{*}{ Social skill } & Cooperation & $23.64 \pm 9.47$ & $23.89 \pm 9.29$ & -.079 & $.938^{\mathrm{NS}}$ \\
\hline & Assertion & $24.23 \pm 8.74$ & $24.10 \pm 8.55$ & .045 & $.964^{\mathrm{NS}}$ \\
\hline & Self control & $26.41 \pm 9.11$ & $26.10 \pm 8.81$ & .102 & $.919^{\mathrm{NS}}$ \\
\hline
\end{tabular}

${ }^{\mathrm{z}}$ Mean \pm Standard deviation

${ }^{\mathrm{NS}}$ Non significant at $p<.05$ leveled by t-test

ducted the test for homogeneity of variance, and the Levene test results were social skills $.05<p=.962$ self-determination skills $.05<p=.795$, assuming equal variance, and the results of analyzing the independent samples t-test are shown in Table 2. In all sub-items of self-determination skills such as behavior $(p=.653)$, cognition $(p=.760)$, school support $(p=.856)$, and family support $(p=.737)$, $p$-value was greater than 0.05 , thereby showing no significant difference between the two groups. Moreover, in all sub-items of social skills such as cooperation $(p=.938)$, assertion $(p=.964)$, and self-control $(p=.919), p$ - value was also greater than .05 , thereby showing no significant difference. In other words, the control group and experimental group are homogeneous and thus this study could be conducted.

\section{Pretest-posttest within groups}

\section{Changes in self-determination skills}

Prior to the analysis, the population was small with 17 subjects in the experimental group and 19 subjects in the control group, which is why we tested normality. The Kolmogorov-Smirnov test showed the result of experimental group $P=.200>.05$ and control group $P=.066>.05$, and the Shapiro-Wilk test showed the result of experimental group $P=.453>.05$ and control group $P=.358>.05$, indicating that both groups had normality. Therefore, a paired t-test was conducted. We analyzed the changes in self-determination skills of the control group and the experimental group after the program in 4 sub-domains (behavior, cognition, school support, family support) using a paired t-test. The results showed that the control group showed no significant difference in all of behavior $(p=.887)$, cognition $(p=.078)$, school support $(p=.130)$, and family support ( $p=.136)$ (Table 3 ). On the other hand, the experimental group showed statistically significant differences in all 4 sub-domains such as behavior $(p<.001)$, cognition $(p<.001)$, school support $(p<.001)$, and family support $(p=.001)$. In other words, carrying out the theme-based garden book (photo book) making integration program had positive effects on improving self-determination skills of students. As for the pretest-posttest difference in mean scores by item, the mean of behavior increased from 3.48 to 3.51 in the control group and from 3.35 to 4.22 in the experimental group; the mean of cognition increased from 3.43 to 3.03 in the control group and from 3.52 to 4.49 in the experimental group; the mean of family support increased from 3.31 to 3.07 in the control group and from 3.30 to 4.43 in the experimental group; and the mean of school support increased from 3.63 to 3.25 in the control group and from 3.52 to 4.28 in the experimental group, proving that the means in the experimental group increased with significance in all items, whereas the control group showed insignificant increases that were not significant. As a result of carrying out the theme-based garden book (photo book) making integration program using capstone design teaching on college students with developmental disabilities, the program created a mood for sufficient rapport building with a teaching method in which students can freely express themselves, thereby expressing, presenting, and deciding on their thoughts and behaviors. Accordingly, the program brought positive ef- 
Table 3. Self determination skill among control and experimental groups, before and after making a garden book with theme integration program

(unit: Score)

\begin{tabular}{cccccc}
\hline \multirow{2}{*}{ Group } & \multirow{2}{*}{ Item } & $\mathrm{N}$ & Before & After & \multirow{2}{*}{$p$} \\
\cline { 4 - 5 } & & & Mean \pm SD & Mean \pm SD & \\
\hline \multirow{3}{*}{ Exp. } & Behavior & 17 & $3.35 \pm 0.94$ & $4.22 \pm 0.56$ & $<.000^{*}$ \\
& Cognition & 17 & $3.52 \pm 0.82$ & $4.49 \pm 0.26$ & $<.000^{*}$ \\
& School support & 17 & $3.30 \pm 0.77$ & $4.43 \pm 0.22$ & $<.000^{*}$ \\
& Home support & 17 & $3.52 \pm 0.98$ & $4.28 \pm 0.45$ & $.010^{*}$ \\
& Behavior & 19 & $3.48 \pm 0.85$ & $3.51 \pm 0.55$ & $.887^{\mathrm{NS}}$ \\
& Cognition & 19 & $3.43 \pm 0.89$ & $3.03 \pm 0.73$ & $.078^{\mathrm{NS}}$ \\
& School support & 19 & $3.31 \pm 0.80$ & $3.07 \pm 0.68$ & $.130^{\mathrm{NS}}$ \\
& Home support & 19 & $3.63 \pm 0.91$ & $3.25 \pm 0.57$ & $.136^{\mathrm{NS}}$ \\
\hline
\end{tabular}

${ }^{\mathrm{z}}$ Mean \pm Standard deviation

${ }^{\mathrm{NS}}$ Non significant, Significant ${ }^{*} p<.05$ by paired t-test.

fects in all sub-items of self-determination skills. This is in line with the study proving that forest garden activities through nature relieve stress of children with disabilities, and activities using plants allow students with developmental disabilities who have difficulty managing their stress to freely express themselves in a relaxing and comfortable atmosphere (Hwang, 2019). This result is also similar to the study that various programs that integrated garden activities develop career attitudes (Jang, 2019), because stress management is related to attitudes toward career as well (Kim, 2017). In particular, unlike the control group in the class focused on theories, using capstone design that provides a sense of closeness and induces active participation before the project in free laboratory settings (On, 2019) displays a synergy, thereby bringing positive effects to all sub-domains of self-determination skills, even school and family support, for college students with developmental disabilities that are not familiar with self-expression. This is consistent with the result of previous studies proving that horticultural activities have positive effects on competency enhancement of students with developmental disabilities (Kim, 2016; Lee et al. 2019). In other words, plant-related horticultural activities and garden design are both expressive experiences that increase positive emotions, thereby contributing to improving self-determination skills such as 'making one's own decisions and choices' as well as 'self-assertion' and 'self-care' skills. Building enough rapport in advance and carrying out visually stim- ulating activities for sufficient motivation and expression of inner thoughts, instead of focusing only on physically creating the theme garden, may have played a significant role. This result also supports a previous study claiming that making a book with photos is a visual support, and static stimulation like photos instead of dynamic stimulation like videos provides enough time to concentrate, thereby more effective for self-determination of persons with developmental disabilities (Park, 2018). Furthermore, visual perceptual stimulation activities of book (photo book) making (Hue, 2009) may have created a synergy in convergence with garden design. In particular, Cafiero (1998) stated that people with autism spectrum disorder are interested in activities using visual clues, which help them concentrate on stimulations and remember information, while also facilitating retrieval of remembered information. Those with autism spectrum disorder tend to better understand through visual information than verbal. Hong (2012) claimed that developmental disabilities include autism spectrum disorder, and there are many cases in which one with intellectual disability also has autism spectrum disorder or vice versa. Thus, the results of this study on developmental disabilities partially proved the theory by Cafiero (1998) as well.

\section{Changes in social skills}

Prior to the analysis, the population was small with 17 
subjects in the experimental group and 19 subjects in the control group, which is why we tested normality. The Kolmogorov-Smirnov test showed the result of experimental group $P=.185>.05$ and control group $P=.200>.05$, and the Shapiro-Wilk test showed the result of experimental group $P=.137>0.05$ and control group $P=.906>.05$, indicating that both groups had normality. Therefore, a paired t-test was conducted. As a result of the pretest-posttest comparison with a paired t-test on 3 sub-items of social skills of the control group and the experimental group that participated in the program, cooperation showed a significant difference in both the control group $(p=.048)$ and experimental group $(p<.001)$. However, the control group did not show a significant difference in assertion $(p=.548)$ and also in self-control $(p=.975)$, whereas the experimental group showed a significant difference in both assertion $(p<.001)$ and self-control $(p<.001)$ (Table 4). Carrying out the theme-based garden book (photo book) making integration program had positive effects on social skills of students such as assertion and self-control. However, both the control group $(p=.048)$ and experimental group $(p<.001)$ showed a significant difference in cooperation, failing to prove that this program affects cooperation from social skills. However, assertion or self-control is a competency that can be mostly improved in creative integration programs like theme-based garden book (photo book) making, thereby showing clearly significant results. As for the pretest-posttest difference in mean scores by item, the experimental group showed significant improvement in all items, such as cooperation that increased by 9.83 , assertion that increased by 6.59 , and self-control that increased by 3.10. This may be due to the fact that there was much environmental and human help through intensive support in the student-oriented capstone design teaching, rapport building through theme development of the theme garden, and book (photo book) making, which can be a topic of further research. Moreover, practical exercises using plant materials induced great interest from college students with developmental disabilities, and thus the experimental group participated more enthusiastically in class than the control group that did not participate in the program, thereby showing significant improvement in all sub-items. Furthermore, theme-based garden book (photo book) making helps members continuously share and mediate their opinions to achieve the goal, closely communicate to solve problems, and become more familiar with understanding and expressing emotions, thereby learning what others think and at the same time organizing their own thoughts. This enabled them to find their values and interests or solve problems, and this mature self-determination led them to experience that their rights as well as other people's rights are respected, thereby improving social skills. This is in line with the study by Hue (2009) claiming that experiencing various stages of introspection through the process of planning, editing, and completing a book helps polish up self-control, thereby having positive effects on improvement of social skills. Meanwhile, garden activities promote physical health with gross motor and fine motor skills by digging into the ground or transplanting plants (Cameron, 2016), while also increasing the attempt to eat new fruits or vegetables for

Table 4. Social skill among control and experimental groups, before and after making a garden book with theme integration program

(unit: Score)

\begin{tabular}{|c|c|c|c|c|c|}
\hline \multirow{2}{*}{ Group } & \multirow{2}{*}{ Item } & \multirow{2}{*}{$\mathrm{N}$} & Before & After & \multirow{2}{*}{$p$} \\
\hline & & & Mean \pm SD & Mean \pm SD & \\
\hline \multirow{3}{*}{ Exp. } & Cooperation & 17 & $23.64 \pm 9.47$ & $33.47 \pm 4.10$ & $0.00 *$ \\
\hline & Assertion & 17 & $24.23 \pm 8.74$ & $30.82 \pm 7.01$ & $0.00 *$ \\
\hline & Self control & 17 & $26.41 \pm 9.11$ & $31.29 \pm 5.79$ & $0.00 *$ \\
\hline \multirow{3}{*}{ Cont. } & Cooperation & 19 & $23.89 \pm 9.29$ & $20.47 \pm 5.91$ & $.048 *$ \\
\hline & Assertion & 19 & $24.10 \pm 8.55$ & $25.00 \pm 4.28$ & $.548^{\mathrm{NS}}$ \\
\hline & Self control & 19 & $26.10 \pm 8.81$ & $26.05 \pm 5.67$ & $.975^{\mathrm{NS}}$ \\
\hline
\end{tabular}

${ }^{\mathrm{NS}}$ Non significant or significant at ${ }^{*} p<.05$ 
a healthy dietary life. This positively affects social interactions, increases confidence, and builds mutual relationships, thereby contributing to social growth (Passy et al, 2010). This study also confirmed that the activity of designing a theme garden contributes to social skills with cooperation, assertion, and self-control like other garden activities.

\section{Conclusion}

This study implemented a theme-based garden book (photo book) making integration program using capstone design teaching and determined how it affects self-determination and social skills. The results of examining the pretest-posttest changes in self-determination and social skills of the control group and experimental group proved that the experimental group that participated in the program showed statistically significant differences in all 3 sub-domains of social skills, such as cooperation $(p<.001)$, assertion $(p<.001)$, and self-control $(p<.001)$. However, the control group that did not participate in the program did not show statistically significant differences in 2 sub-domains of social skills, such as assertion $(p=.548)$ and self-control $(p=.975)$, but showed a significant change in cooperation $(p=.048)$. Thus, we failed to prove that the increase in cooperation among the sub-domains of social skills in the experimental group is brought by the effect of the theme-based garden book (photo book) making program. Meanwhile, self-determination skills were comprised of 4 sub-domains, and the control group did not show significant differences in all of them, such as behavior $(p=.887)$, cognition $(p=.078)$, school support $(p=.130)$, and family support $(p=.136$ ) (Table 3$)$. Meanwhile, the experimental group showed statistically significant differences in all 4 sub-domains, such as behavior $(p<.001)$, cognition $(p<.001)$, school support $(p<.001)$, and family support $(p=.001)$. In other words, implementing the theme-based garden book (photo book) making integration program brought positive effects to all sub-domains of self-determination skills for students. Therefore, this study statistically verified that the theme-based garden book making integration program mediated by garden design activities may contribute positively to the improvement of self-determination and social skills, which are fundamental qualities for social adjustment as the educational objective of college students with developmental disabilities. In other words, we objectively determined that applying an integration program using garden design to social adjustment education for college students with developmental disabilities is effective and that garden design activities can be used in an integration program. The results of this study are significant in that it provided the case in which garden design activities not only produced physical design outcomes but also brought educational effects by promoting verbal and nonverbal self-expression in the form of a theme garden. More detailed analysis of the program's effects will be conducted in follow-up research.

\section{References}

Cameron, R. 2016. The university of sheffield and the royal horticultural society, gardening its value in terms of human health and well-being? Ornamental horticulture roundtable, Health \& Hort. Conference. Retrieved form https://www.rhs.org.uk/science/Ornamental-Horticulture -Roundtable/Health-and-Horticulture-Conference-2016

Cafiero, J. 1998. Communication power for individuals with autism. Focus Autism Other Dev. Disab. 13(2):113-121. https://doi.org/10.1177/108835769801300208

Cavell, T.A. 1990. Social adjustment, social performance, and social skill; A tri-component model of social competence. J. Clin. Child. Psychol. 19(2), 111-122

Elliot, S.N. and F.M. Gresham. 1990. Social skill rating system circle pines, MN: American Guidence Service.

Gresham, F.M. 1981. Social skills training: Should We Raze, Remodel, or Rebuild? J. Behavioral Disorders, 24(1),19-25. Retrieved form https://www.jstor.org/stable/23888736

Hwang, Y.A. 2019. The effects of forest experience activities on preschool children's stress, self-regulation, resilience, and disposition change. Master's thesis, Gachon University, Gyeonggi-do, Korea.

Hong, J.K. 2012. The effects of job search program on career attitudes \& self-determination skills for college students with developmental disabilities. Master's thesis, Korea Nazarene University, Korea. 
Hue, H.J. 2009. The effects of book making program with daily life photo on autistic disorders spontaneous requirement. Master's thesis, Gongju University, Chung-Nam, Korea.

Jang, J.E. 2019. The effect of STEAMS gardening activity programs on developing career education of senior elementary school students. Master's thesis, Korea University, Seoul, Korea.

Kim, D.R. 2011. The effects of cultural english class based on internal factors of vocational adaptation on vocational readiness for college students with developmental disabilities. Doctoral dissertation, Dankook University, Seoul, Korea.

Kim, H. J. 1996. Study for the Validation of social skill. Korean J. Spec. Educ. 7(1),121-155.

Kim, S.N. 2013. The effect of cooperative book-making activities through using stories on young children's prosocial behavior. Master's thesis, Early Childhood Education Graduate school of Education Korea National University of Education, Chung-Buk, Korea.

Kim, S.Y. 2016. Development of competency-based horticulture rehabilitation assistant curriculum for disability university students. J. Korean Soc. People Plants Environ. 19(6):595-604. https://doi.org/10.11628/ksppe.2016.19. 6.595

Kim, S.Y. 2017. Effects of competency-based instructional design of indoor gardening course on job performance for university students with disabilities. J. People Plants Environ. 20(6):629-638. https://doi.org/10.11628/ksppe. 2017.20.6.629

Kim, S.Y. 2018. Development of competency-based horticulture rehabilitation assistant curriculum for developmental. Master's thesis, Korea Nazarene University, Cheonan, Korea.

Lee, S.M., N.R. Jeong, S.H. Jeong, G.M. Gim, K.S. Han, Y. Chea, K.J. Kim, and H.J. Jang. 2019. Consideration of programs and operations of farms providing agro-healing service. J. People Plants Environ. 22(1):1-14. https://doi.org/10.11628/ksppe.2019.22.1.001

Lee, S.J., S.M. Lee, and J.K. Suh. 2012. The conceptual frame of horticultural therapy as vocational training (H.T.V.T.) for adolescents with intellectual disabilities. J. Korean Soc. People Plants Environ. 15(5):307-318.

On, G.Y. 2019. The Relationship between self efficacy for group work, achievement goal orientation, social support, and learning outcomes in capstone design learning for engineering education. Master's thesis, Graduate school of Ewha Womans University, Seoul, Korea.

Park, J.W. 2018. Effects of Cooperative art treatment on the social technological of adults with developmental disabilities. Master's thesis, Daegu university, Gyeongbuk, korea.

Passy, R., M. Marian, and R. Frances. 2010. Impact of school gardening on learning. Natl. foundation for educational res. National children's gardening week. Retrieved form https;//www.childrensgardeningweek.co.uk

Rhyou, S.R. 2002. Development of a program for self determination activity and effects of the program on the level of self determination for students with mild disabilities in transition period. Doctoral dissertation, Ewha women's University, Seoul, Korea.

Roseth, C.J., D.W. Johnson, and R.T. Johnson. 2008. Promoting early adolescents, achievement and peer relationship; The effect of cooperative, competitive, and individualistic goal structures. Psychol. Bull. 134(2),223-246. https://doi.org/10.1037/0033-2909.134.2.223

Royal Horticultural Society. 2018. RHS campaign for school gardening. Retrieved form https://www.rhs.org.uk

Act on the Guarantee and support of human rights with developmental disability. Act No. 16736. 2019. Retrieved from http://www.moleg.go.kr 